\title{
KAMU HUKUKU
}

\section{ÜMANIST DOKTRIN AÇISINDAN «ÖZEL KAST»}

Yazan : Prof. Dr. Faruk EREM

«Saik» in cezayı azaltan, arttıran sebep veya suçları ayırıcı ölçü ve bilhassa suçun «sübjektif unsur»u olarak kanunda nazara alınması halinin ayrıca incelenmesi gereklidir (1). Özel kasdın (veya daha geniş olarak saik'in) doğmatik-hukuk değeri olmadığı, genel kasitta esasen mevcut olan özel kastın ayrıca nazara alınmasının bir faydası olamıyacağı, özel kastın sadece suç sebepleri arasında geleneksel bir kabulden faydalandığı ileri sürülmemiş değildir (2). Fakat saiki değersiz görmek, onu izah etmek sayılmaz (3).

1. Neticenin neticesi anlayışı: Bu anlayıșı benimseyenlere göre özel kast, hareketin neticesine bağlı ve netice sonrası bir durumun (neticenin neticesinin) hareketten evvel tasavvuru ve böyle bir tasavvurun fiile sebep olmasıdır. Bu anlayışta geniş anlamda bir kast kavramı içinde özel bir kast değil, kast kavramı dışında (4) bir «sebeb» bahis konusudur. 0 halde «özel kast» deyimi de hatalıdır. «Fiilin gayesi» deyimi daha yerindedir.

2. Kast içi anlayış: Özel kast, daha dar tutulan bir kasittan ibarettir. Bu anlayıșa göre «netice» nin neticesini de istemek iradesinin mevcut bulunması şartı ile kanunun saymağı uygun gördüğï fiillerde özel kast aranmıștır. Böyle bir kastın bulunmaması halinde suç sayılmayan bir fiilin böyle bir kast bulunduğu için suç sayıl-

(1) bk. Contieri (E.), lo scopo dell'autore del reato e la colpevolezza psicologica (Archivio penale, 1947, fase. 5-6, ss. 217.

(2) Maggiore (- nin fikri, Contieri'den naklen, s. 18, nt. 8; bk. Merle-Vitu, s. 445 , nt. 1.

(3) Carnelutti (F.), Teoria generale del reato (Padova, 1933), s. 55.

(4) Antolisei (F.), Manuale di diritto penale (Milano, 1960), n. 128, A; bk. Dönmezer - Erman nazarî ve tatbiki ceza hukuku, II/1 (İstanbul, 1959) n. 940 , a; bk. Altavilla (E.), Lineamenti di diritto criminale (Napoli, 1932), s. 202. 
mış olduğu hallerde daha daralmıș (özelleșmiș) bir kast bahis konusudur. "Özel kast, genel kasttan ayrı bir kavram değildir. Onun bir vasfıtır» şeklinde düşünenleri de (5) aynı anlayıș içinde kabul edebiliri: $:$ Özel kasıtta, genel kasta nazaran «daha özel bir șuurun arandığgı (6). «özel kastın, daha yoğun bir genel kasıttan ibaret olduğu», "özel kastın daha vazıh bir kast» sayılması gerektiği (7) mütalâaları da aynı niteliktedir. Bu sonuncu düșüncede, yani genel kastın bəlirli bir kötülük üzerinde vuzuh kazanmadığı, mağdurun mümkür olan herhangi zarardan birisine uğramasının istendiği, hususî kasıtta ise zararın tâyin edilmiş olacağ ileri sürülmektedir (8). Fakat bu anlayış özel kastı, muayyen olan ve olmayan kast konusuna sokmuş olur ki kavramlar birbirlerine karıştırılacaktır.

3. Suçları ayırıcı saik: Maddî yapısı aynı olan suçları birbirinden ayırmada görevli saik, "Suçları ayırıcı saik» tir. Bu saik, mevcut değji! ise, fiilin suç olmaması anlamına gelen saikten ayrıdır.

Bununla beraber saikin yalnız suçları ayırıcı görevi içinde kabulünün mü̈mkün olduğunu, "özel kast» olarak saikin kabulünün doğru olamıyacağını düşünenler de vardır (9). Fakat bu düşünce isabetli değildir, "suçları ayırıcı saik" esasında "özel kast» tan başka bir ફ;ey değildir. Özel kasta göre suçları ayırt edebilmek, özel kastın riteliğini değiştirmiș olamaz. «Mütenavip özel kast» (șehvet hissi veya evlenme maksadiyle kaçırma gibi, TCK. 429) hallerinde de: (10) durum aynidir.

4. Hareketin gayesi-saik: Bir hareketin neticesi onun maddî olarak ğerçekleșmiş gayesidir. Failin saiki ile hareketin ulaştığı gaye her :aman aynı değildir. Ceza kanunlarında kullanılan, belirli bir gayeye «...matuf fiil» deyimleri (bk. TCK. 141) üzerinde durulmak ge ektir. Bu deyimlerin altında gerekirse, bazı haksızlıkları da göze alınak isteği saklıdır. Malûm ve ünlï «her ne suretle olursa olsun» formülï de aynı niteliktedir. Halbuki "saik» e bağlı kalmak daha ir sancadır. O halde -bu anlamda- "saik» ve "gaye» ayrı kavramlarclır. "Maksat», «niyet» kavramlarına saikten farklı anlamlar da verilebilir (11).

(5) Piacenza (- nin fikri, Contieri'den naklen, s. 222.

(6) Bcttaglini (G.), Diritto penale (Parte generale, Bologna, 1940), n. 63.

(7) Cavallo (V.), Diritto penale, II (Napoli, 1955), n. 201; Merle (R.) Vitu (a.), Traité de droit :riminel (Paris, 1967), n. 451.

(8) Tuozzi (P.). Corso di diritto penale, I, s. 141.

(9) bk. Maggiore (G.). Principi di diritto penale, I (Bologna, 1937), s. 370.

(10) Manzini (V.), Trattato di diritto penale italiano, I (Torino. 1926), $\mathrm{n}$. $253, \mathrm{~b}$.

(11) kșz. Bettiol (G.), Diritto penale (Palermo, 1962), s. 368. 
5. Neticenin neticesi kavramının analizi: Genel kast, hareketin «neticelerini bilerek ve isteyerek işlemek iradesi» şeklinde kabul clunursa genel-özel kast ayrımı mümkün değildir. Çünki bilinen ve istenen her çeşit netice genel kast içinde kalacak, özel kasta konu bulunamiyacaktır.

a) Doğal olmayan netice : «Özel kast» diye isimlendirilen kavrammn konusu hareketin maddî, doğal neticesi olamaz. Saikin, cezaya etkili olduğu hallerde de bu böyledir. Yeni doğmuş çocuğun «şeref kurtarma saiki» ile öldürülmesinde şerefin kurtarlması hareketin doğal neticesi değildir. Hareket böyle bir netice vermiş kabul ediism. Acaka bu neticeyi, tecrit edilmiș bir hareket mi doğurdu?

O halde saikin konusu olarak kabul edilebilecek «netice», kastın tanımında yer alan neticeden 'ayrı nitelikte bir kavramdır. Özel kasıtta da bir «netice»yi «bilmek» ve «istemek» vardır. Fakat bilinen ve istenen netice, genel kasıttaki neticeden başka niteliktedir.

Genel kasdı, ceza hukukunda, hareket kavramından (bunun neticelerini bilmek ve istemekten) çıkarmaktayız. Halbuki özel kasdı hareketin doğal neticelerine göre tâyin mümkün değildir.

b) Genel olarak saik: Bir "saik» i olmayan suç düşünülemez. O halde neden her suçta "özel kast" aranmamıştır? Çünki genel kastın subutunda saik fiilen aranmaktadır. Nitekim saikin kanunda ayrıca nazara alınmadığı hallerde "genel takdir hakkı» na etkili olacağı tabiidir, hatta bazı kanunlar açık bir hükümle saikin cezanun takdirinde nazara alınması lüzumunu belirtmişlerdir (12). Ferri, saikin kasıttan ayrılmasının imkânsızlığını ileri sürerken haksız değildi : Hırsız, (kleptomani hariç) çalmak için çalmaz, faydalanmak için çalar, sadece adam öldürmek için öldürülmez, bunun bir saiki vardur (intikam, nefret, menfaat, hatta fanatizm) (13).

«Özel kast» bir başka anlamda olmalıdır. Kanun, hareketin doğal olmayan neticelerinden bazılarını bir kıymet hükmüne bağlamak zaruretini duyduğu (veya zan ettiği) olaylarda saiki özel kast saymıştır. Özel kastı, kanunun, «hareketin doğal olmayan neticeleri hakkında bir kıymet hükmü vermek istediği hallerde saiki nazara almış olmasıdır» şeklinde tarif etmek mümkündür.

$\mathrm{Bu}$ açıdan ele aldığımız da saike kanunun hukukî etki tanıdığı hallerde, etkinin çeşidi esasla ilgili değildir. "Faydalanmak niyeti» nin «hırsızlık» 1, "nası izrar» dan ayırması, cezayı «kan gütme saiki»

(12) İsviçre CK. 63; Logoz, I, m. 63, n. 4, a;

(13) Ferri (E.), Principii di diritto criminale (Torino, 1928), s. 441. 
nin arttıması, «şeref kurtarma asiki» nin cezayı azaltması ile bayrağı yırtrnada «hakaret saiki» nin bazı birleşmelerde cemiyet kurmada "suç işlemek saiki» nin (TCK. 313) özel kast sayılması arasinda esasta fark yoktur.

c) Özel kast ve niyet: Eğer genel kast "hareket» ve "netice» esas tutularak ve bunlara ilişsin «şuur» ve "irade» kavramlarına dayanılarak tarif edilecek ise ve özel kast, niyet anlamında «saik» olarak düşünüliuyorsa özel kastın genel kastın başladığı şuur ve irade alanindan önceye ait olması gerekir. Böyle olunca özel kastı, «kast içi kavram» saymak mümkün olamiyacaktır (14).

६) Maddî hata: Genel-özel kast arasındaki ilgiyi, maddî hatanin etkisine bakarak, daha berrak görebiliriz. Maddî hatanın, genel kastı kaldırdığı hallerde özel kast mevcut olmakta devam edebilir mi? Maddî hatanın genel kastı kaldıracağı, fakat özel kasta hiç bir șekilde etkili olamıyacağ ileri sürülmüsstür (15). Bu görüşün doğru olmaması mümkündür. Çünki çoğu tahrip edenin aza etkisizliği düşünülemez. Bu açıdan «kast içi anlayış» a katılmak mümkündür. Burnunla beraber maddî hatanın genel kastı gidermesi, daha dirençli özel kasta etkili olmaması da düşünülebilir. Kızkardeşinin şerefini kurtarmak saiki ile onun doğurduğu çocuk yerine, hata sebebi ile bir bașka çocuğu öldüren erkek kardeş beraet mi edecektir?

6. Özel kastın kabulünde ölçü: Saikin özel kast olarak kabulïnde kanun koyucunun keyfiliğgi esas tutulamaz. Bunun mutlaka bir ölçüsü olmak gerektir. Bu ölçüler arasında «ümanist değer hükümleri” de yer almaktadır.

Mehaz kanun adam öldürme suçları hakkındaki hükmünde «kasıt» tan bahsetmemiş, bunun bütün suçlar için genel hükümlerde gösterildiğini düșünmüss, fakat bundan ayrı olarak «öldürmek niyeti» ne ihtiyaç olduğunu açılamıștır. Kanunumuzda, 45. maddenin sarahatine rağmen, 448. maddede «kasten öldürmek» denmiş, bu suretle adam öldürme suçu -bir anlayışa göre- özel kastlı suç olmaktan çıkarılmıștır. Acıma duygusu ile öldürme, organ nakli gibi olaylarda faile «katil» demenin kanunen zarurî, vicdanen imkânsız oluşunun sebeplerinden birinin de bu olabileceği düş̧ünülebilir. Fakat mehaz kanunda, kasten katil ile «müessir fiilden telefi nefis» (TCK. 452) meydana gelmesini ayırt edebilmek üzere «öldürmek niiyeti» nden bahsolunduğu da ileri sürülebilir (16).

(14) kși. Vannini (O.), La dottrina del dolo e i reati di pericolo (Milano, 1917), s. 9.

(15) Merle - Vitu, n. 452.

(16) kş̧:. Vannini, s. 9. 